\title{
Re-evaluation of the age model for North Atlantic Ocean Site 982 - arguments for a return to the original chronology
}

\author{
K. T. Lawrence ${ }^{1}$, I. Bailey ${ }^{2}$, and M. E. Raymo ${ }^{3}$ \\ ${ }^{1}$ Lafayette College, Department of Geology and Environmental Geosciences, 102 Van Wickle Hall, \\ Easton, PA 18042, USA \\ ${ }^{2}$ National Oceanography Centre Southampton, University of Southampton, European Way, Southampton, SO14 3ZH, UK \\ ${ }^{3}$ Lamont-Doherty Earth Observatory, P.O. Box 1000, 61 Route 9W, Palisades, NY 10964, USA
}

Correspondence to: K. T. Lawrence (lawrenck@lafayette.edu)

Received: 23 March 2013 - Published in Clim. Past Discuss.: 29 April 2013

Revised: 20 July 2013 - Accepted: 1 October 2013 - Published: 25 October 2013

\begin{abstract}
Recently, the veracity of the published chronology for the Pliocene section of North Atlantic Ocean Drilling Program Site 982 was called into question. Here, we examine the robustness of the original age model as well as the proposed age model revision. The proposed revision is predicated on an apparent misidentification of the depth to the Gauss-Matuyama (G/M) polarity chronozone reversal boundary $(2.581 \mathrm{Ma})$ based on preliminary shipboard paleomagnetic data, and offers a new chronology that includes a hiatus between $\sim 3.2$ and $3 \mathrm{Ma}$. However, an even more accurate shore-based, u-channel-derived polarity chronozone stratigraphy for the past $\sim 2.7 \mathrm{Ma}$ supports the shipboard composite stratigraphy and demonstrates that the original estimate of the depth of the G/M reversal in the Site 982 record is correct. Thus, the main justification forwarded to support the revised chronology no longer exists. We demonstrate that the proposed revision results in a pronounced anomaly in sedimentation rates proximal to the proposed hiatus, erroneous assignment of marine-isotope stages in the Site 982 Pliocene benthic stable oxygen isotope stratigraphy, and a markedly worse correlation of proxy records between this site and other regional paleoclimate data. We conclude that the original chronology for Site 982 is a far more accurate age model than that which arises from the published revision. We strongly recommend the use of the original chronology for all future work at Site 982.
\end{abstract}

\section{Introduction}

Ocean Drilling Program (ODP) Site 982 was drilled on the Rockall Plateau in the subpolar North Atlantic Ocean $\left(58^{\circ} \mathrm{N}\right.$, $16^{\circ} \mathrm{W}$, at $1134 \mathrm{~m}$ water depth) during Leg 162 (Fig. 1). Sediments recovered from Site 982 have been used to generate numerous paleoclimate data sets that have made important contributions to our understanding of past oceanic and climatic changes centered on the North Atlantic region (e.g., Bartoli et al., 2011; Bolton et al., 2011; Lawrence et al., 2009, 2010; Naafs et al., 2012; Pagani et al., 2009; Sosdian and Rosenthal, 2009; Venz and Hodell, 2002; Venz et al., 1999). Recently, Khelifi et al. (2012) have questioned the veracity of the age model for Site 982 that forms the cornerstone of these works. The original age model for Site 982 was published in the initial results volume for ODP Leg 162 (Shipboard Scientific Party, 1996). This age model was refined by Venz and Hodell (2002) and Venz et al. (1999) using oxygen isotope stratigraphy and later minimally adjusted, first by Channell and Guyodo (2004) based on new paleomagnetic data, and later when it was incorporated as one of the records in the global benthic LR04 $\delta^{18} \mathrm{O}$ stack (Lisiecki and Raymo, 2005) (Fig. 2a). We subsequently collectively refer to these chronologies, which are negligibly different for the Plio-Pleistocene, as the "original age model". Here, we explore the validity of both the original age model and the revisions to it proposed by Khelifi et al. (2012) in their Technical Comment to Climate of the Past (Fig. 2a). To this end, we consider the original shipboard Site 982 physical properties data used to develop the 982 composite splice, the Site 982 


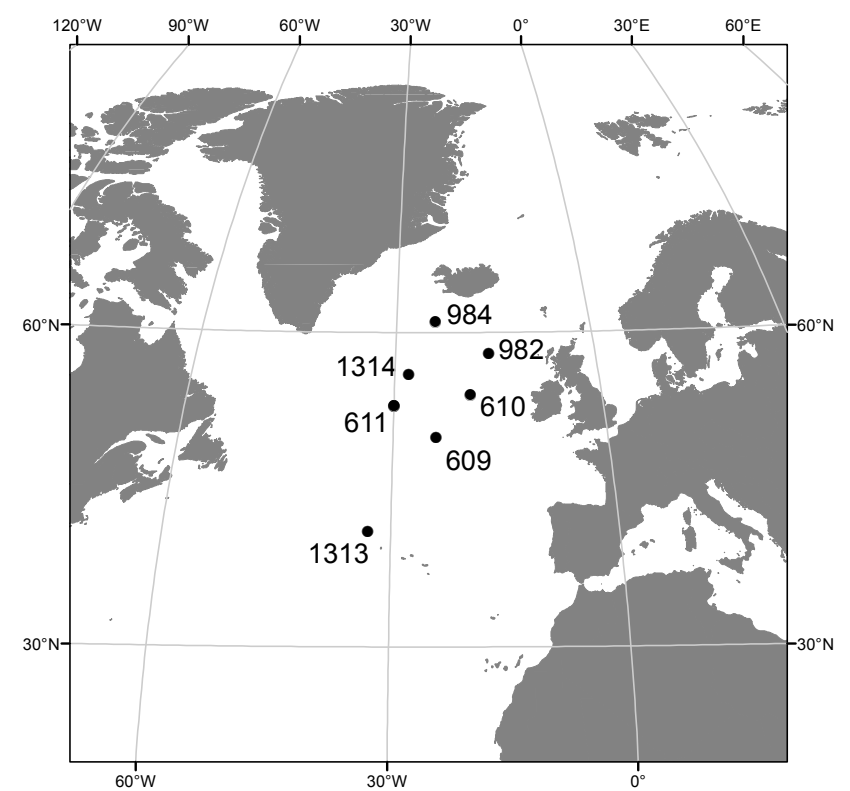

Fig. 1. Site map showing the location of ODP Site 982, as well as other relevant North Atlantic sites.

composite splice itself, subsequently generated shore-based u-channel paleomagnetic data (Channell and Guyodo, 2004), and all available Site 982 benthic oxygen isotope $\left(\delta^{18} \mathrm{O}\right)$ data. We also examine how the paleoclimate data generated from these sites compare to similar records developed from sediments at other localities in the North Atlantic Ocean. In this note, we focus on the disputed interval that falls between 50 and $85 \mathrm{~m}$ composite depth (mcd). As detailed below, this evaluation strongly supports the veracity of the original Pliocene Site 982 age model.

\section{Splices and age models}

\subsection{Original splice and age model}

A composite section for Site 982 was generated down to 597 mcd shipboard by splicing together spectral reflectance and GRAPE data that for the Pliocene portion of this record come from holes A and B (Fig. 3). Various age models have been assigned to this stratigraphy by correlation of its benthic $\delta^{18} \mathrm{O}$ for the past $\sim 2.7 \mathrm{Ma}$ to ODP Sites 677 (Channell and Guyodo, 2004; Venz et al., 1999), 846 (Channell and Guyodo, 2004) and 849 (Flower et al., 2000), for the past 3.2 Ma to Deep Sea Drilling Project (DSDP) Site 607 (Venz and Hodell, 2002), and most recently for the past 5.3 Ma to the LR04 stack, following generation of additional $\delta^{18} \mathrm{O}$ data between 68.09 and 160.62 mcd (Lisiecki and Raymo, 2005). The age model assigned to alkenone-derived sea surface temperature (SST) data from Site 982 presented in Lawrence et al. (2009) is the same one assigned to Site 982 during its incorporation into the LR04 stack (Lisiecki and Raymo, 2005).

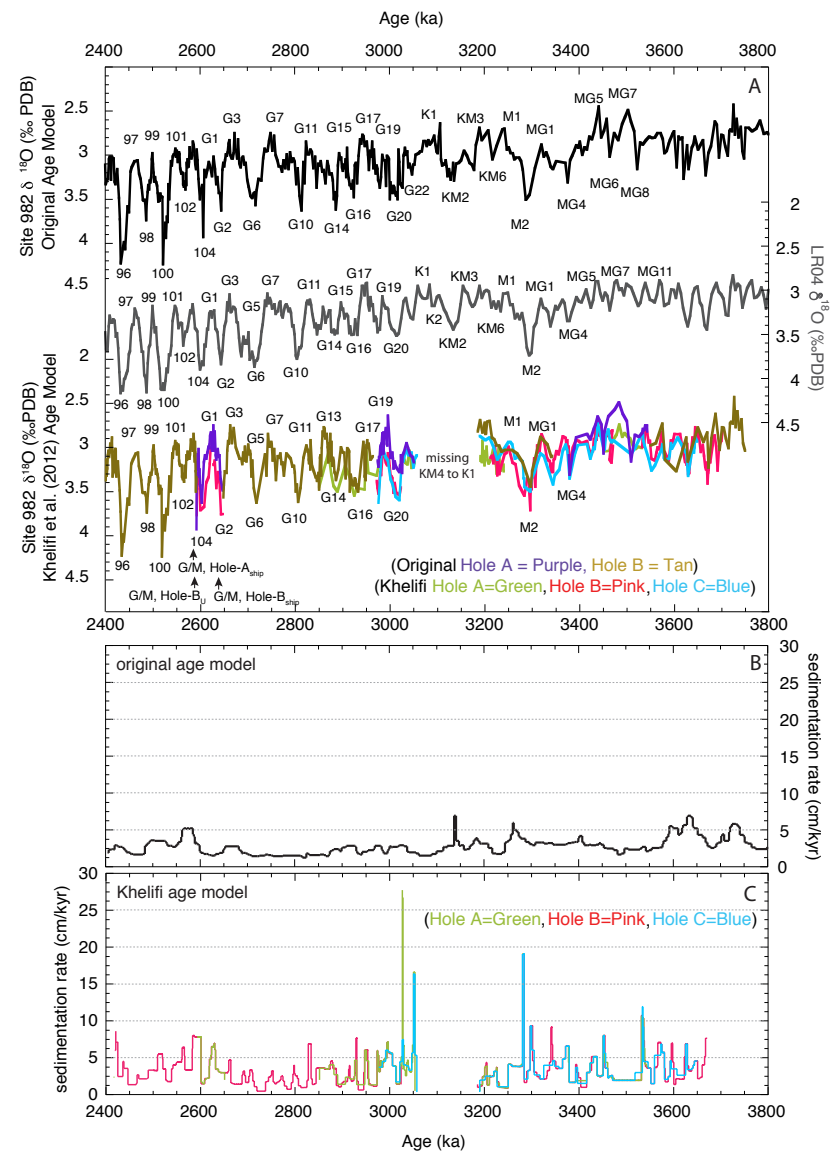

Fig. 2. ODP Site 982 isotopes and sedimentation rates: (A) oxygen isotopes from ODP 982 (Lisiecki and Raymo, 2005; Venz and Hodell, 2002) plotted on the original age model (black) and both the original and Khelifi et al. (2012) isotopes on $\operatorname{rmcd}_{\mathrm{s}}$ of Khelifi et al. (2012) (colors) with associated correlations of both age models with the LR04 oxygen isotope benthic stack (gray) (Lisiecki and Raymo, 2005); (B) sedimentation rates at Site 982 estimated from the original age model (black); (C) sedimentation rates for holes A, B and C estimated from the age model proposed by Khelifi et al. (2012) (colors). Small black arrows and associated labels lower left-hand corner of (A) - indicate the position of the GaussMatuyama chronozone reversal boundary from both shipboard and u-channel measurements.

\subsection{Khelifi splice and age model}

Guided by new benthic foraminiferal $\delta^{18} \mathrm{O}$ data and $\mathrm{U}_{37}^{K^{\prime}}$ SSTs generated on holes A-C, Khelifi et al. (2012) revised the shipboard-derived composite depths between 59.1 and $84.44 \mathrm{mcd}$ to 59.17 and $85 \mathrm{mcd}$ (hereafter referred to as suggested revised $\operatorname{mcd}, \operatorname{rmcd}_{\mathrm{s}}$ ), based on 194 new tie points (contrast with the four tie points used in the shipboard stratigraphy). Khelifi et al. (2012) justify the generation of the $\mathrm{rmcd}_{\mathrm{s}}$ on the basis that, between 55 and $72 \mathrm{mcd}$, the shipboard-derived physical properties data are not characterized by oscillations from which reliable correlations can 

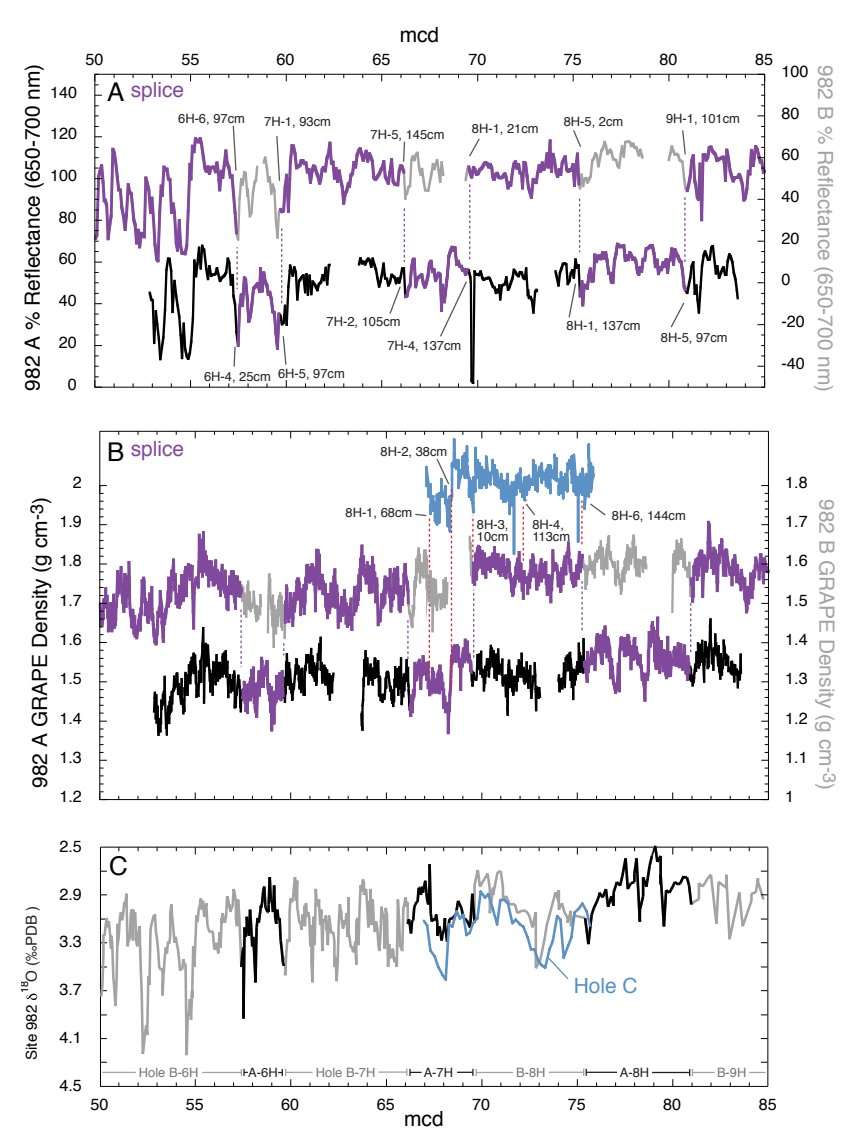

Fig. 3. Site 982 physical properties and benthic oxygen isotope data: (A) shipboard reflectance, (B) shipboard GRAPE density and (C) benthic $\delta^{18} \mathrm{O}$ data for Site 982 holes A, B and C (black, gray and blue data, respectively) and the original shipboard splice (purple data) for the interval of the Site 982 age model in question (Shipboard Scientific Party, 1996). Black labels indicate the samples at core breaks. Dashed vertical purple lines (and labels) denote tie points used to generate the shipboard splice. Dashed vertical red lines (and labels) denote tie points used to tune Hole C GRAPE data to the GRAPE data used to generate the original splice (from Hole A/B). The splice point at Hole A-8H-1, $21 \mathrm{~cm}(69.55 \mathrm{mcd})$, is arguably the least secure tie between holes A and B in the original splice. The Hole C GRAPE data highlight, however, that no stratigraphy is missing from the original shipboard splice due to the inclusion of the tie point at $69.55 \mathrm{mcd}$. Note, no reflectance data was generated for cores 7H-9H in Hole C (Ortiz et al., 1999).

be made (i.e., data drops to background noise). Yet, inspection of the data used to generate the original med indicates that this is not the case (Fig. 3). Plots of the composite benthic $\delta^{18} \mathrm{O}$ records on both splices are slightly different in the depth domain (Fig. 4). The expanded nature of $\operatorname{rmcd}_{\mathrm{s}}$ relative to mcd reflects the very large number of tie points used by Khelifi et al. (2012), which is also responsible for the "better correlation" of $\delta^{18} \mathrm{O}$ between holes in their Fig. 1. Specifically, they have effectively aligned all benthic $\delta^{18} \mathrm{O}$ on the orbital scale between the original shipboard tie points.

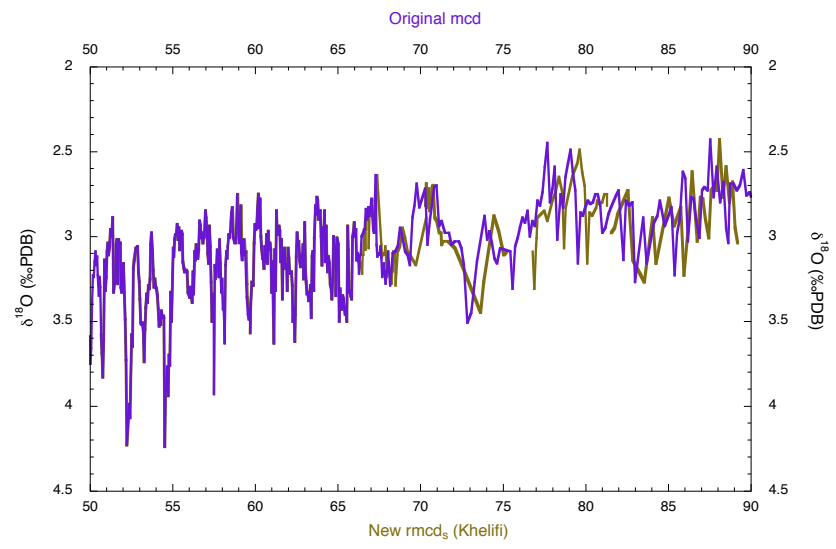

Fig. 4. Comparison of original oxygen isotope data (Venz and Hodell, 2002) on the original mcd (purple) and the $\operatorname{rmcd}_{\mathrm{s}}$ (brown) of Khelifi et al. (2012). Note that there is not a large difference in mcd between the original and the interpretation of Khelifi et al. (2012), rather the significant difference comes in the approaches used to correlate to the LR04 stack (Lisiecki and Raymo, 2005).

All meter scale (glacial-interglacial) cycles in benthic $\delta^{18} \mathrm{O}$ can be recognized in the composite $\delta^{18} \mathrm{O}$ data sets in both records (Fig. 2a). Owing to the large number of tie points used by the Khelifi et al. (2012) composite depth sequence, and therefore the complicated nature of any future sampling plan that would ensue from its use, we recommend that future Pliocene research at Site 982 follow the original mcd. Regardless, given how comparable the original mcd is to $\mathrm{rmcd}_{\mathrm{s}}$ (Fig. 4), it is not the veracity of the splice for the Pliocene that is critical to this work, but rather how it is tuned to the geological timescale (Fig. 2a).

To generate a new age model for Site 982, Khelifi et al. (2012) compressed three meter-scale benthic $\delta^{18} \mathrm{O}$ cycles that in the stratigraphy of the original age model were attributed to MIS K2, G4 and G2 into a much shorter interval, which they now assign, respectively, to MIS G20, G2 and 104. They then proposed the existence of a hiatus, $\sim 130 \mathrm{kyr}$ in duration, that spans most of the mid-Pliocene warm period (MPWP, 3.19-3.06 Ma, MIS KM4-K1). Their justification for these changes hinges on their assertion that the composite depth to the Gauss-Matuyama (G/M) chronozone reversal identified in the original age model at $57.24 \mathrm{mcd}$ (taken from Hole A) should be lower in the section, by $0.78 \mathrm{mcd}$ (to match the mcd attributed to the $\mathrm{G} / \mathrm{M}$ boundary identified shipboard for Hole B at $58.02 \mathrm{mcd}$; 982B $6 \mathrm{H} \mathrm{7W}, 0 \mathrm{~cm}$, $52.55 \mathrm{~m}$ below sea floor, $\mathrm{m}$ b.s.f.). This proposed alteration to the depth of the G/M boundary at Site 982 allowed Khelifi et al. (2012) to redefine isotope stages assigned to individual $\delta^{18} \mathrm{O}$ cycles below $58.02 \mathrm{mcd}$. We believe that these changes are unwarranted.

The revision proposed by Khelifi et al. (2012) centers on the fact that the mid-point depths for $\mathrm{G} / \mathrm{M}$ reversal in holes $\mathrm{A}$ and $\mathrm{B}$, as determined on the ship, do not occur at the same 
composite depth, and that the depth to the G/M boundary in the original mcd is assumed to correspond to the depth identified in Hole A $(50.70 \mathrm{~m}$ b.s.f., $982 \mathrm{~A} 6 \mathrm{H} 4 \mathrm{~W}, 0 \mathrm{~cm})$. In fact, neither ship-determined depth to the G/M boundary in holes A and B falls in the shipboard splice. Nevertheless, Khelifi et al. (2012) argue that the shipboard inclination data used to define the G/M boundary in Hole B (Channell and Lehman, 1999) are superior to those obtained for Hole A. Accordingly, they use the shipboard-derived depth to the $\mathrm{G} / \mathrm{M}$ boundary in Hole B to identify MIS 104 (2.6 Ma, LR04 age), one $\delta^{18} \mathrm{O}$ cycle lower in the mcd than attributed in the original age model.

In constructing age models for marine records, ODP shipboard polarity stratigraphies should always be considered preliminary, because stepwise alternating field demagnetization of natural remanent magnetization (NRM) is not feasible during cruises; most samples are only measured with a single demagnetization step. Shipboard-derived polarity records only represent guidelines for more comprehensive post-cruise age model generation, which can include shorebased u-channel research. Fortunately, and despite the reservations of Khelifi et al. (2012), a comprehensive shore-based polarity stratigraphy was generated for Site 982 following the shipboard composite depths between 7 and $66 \mathrm{mcd}$ that also included the analysis of the section of core in Hole B that preserved the $\mathrm{G} / \mathrm{M}$ chronozone reversal boundary (Channell and Guyodo, 2004). Following treatment of NRM on u-channel samples with alternating field demagnetization at peak fields of 80 and $70 \mathrm{mT}$ and 60 to $20 \mathrm{mT}$ (in $5 \mathrm{mT}$ steps), the precise depth of the G/M chronozone boundary in Hole B has been identified at $57.29 \mathrm{mcd}(51.77 \mathrm{~m}$ b.s.f., $982 \mathrm{~B}-6 \mathrm{H}-6$ at $77 \mathrm{~cm}$, Channell and Guyodo, 2004; J. Channell, personal communication, 2012) (Fig. 5), which compares favorably (within $5 \mathrm{~cm}$ ) with the shipboard-derived depth of the G/M chronozone reversal boundary in Hole A $(57.24 \mathrm{mcd})$. This depth in the original age model (= interglacial MIS 103; Channell and Guyodo, 2004) corresponds well to our understanding of the temporal relationships between the G/M chronozone reversal and records of benthic $\delta^{18} \mathrm{O}$ (Ohno et al., 2012) (Figs. 2, 5).

\subsection{Sedimentation rates}

Through the generation of a u-channel polarity stratigraphy, Channell and Guyodo (2004) confirmed that the depth of the G/M chronozone boundary in the Site 982 shipboard splice is $57.29 \mathrm{mcd}$. Through the correct application of the finalized Site 982 polarity stratigraphy, we demonstrate that the major argument forwarded by Khelifi et al. (2012) to justify a revision of the Site 982 age model introduces erroneous changes to the Site 982 chronology. By using the correct depth for the G/M reversal in the Site 982 stratigraphy (at $57.29 \mathrm{mcd}$ ), we negate the proposed need to compress the $\delta^{18} \mathrm{O}$ cycles assigned to MIS G4 and 104 in the original age model and the subsequent introduction of an $\sim 130 \mathrm{kyr}$ hiatus at $70.09 \mathrm{mcd}$. Such a hiatus would introduce unrealistic changes in sedimentation rates within the Pliocene portion of the Site 982

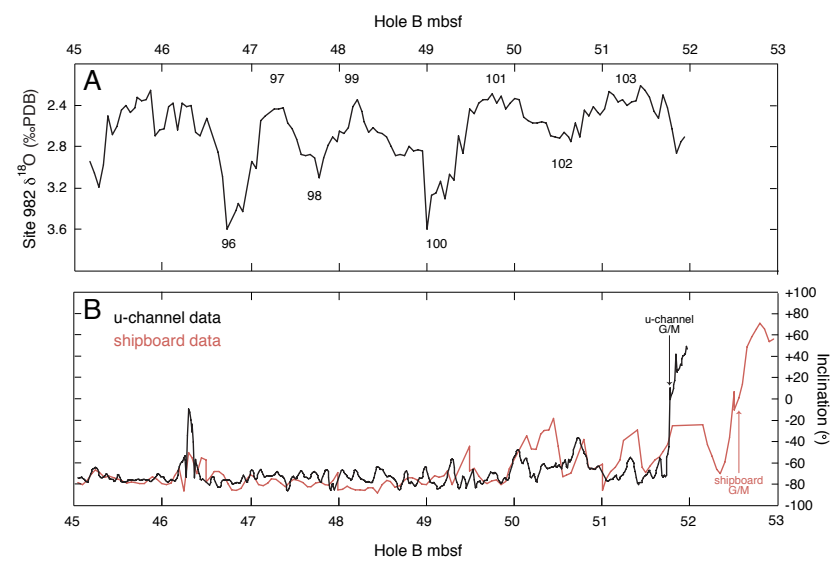

Fig. 5. ODP Site 982 benthic $\delta^{18} \mathrm{O}$ and shipboard and u-channelderived magnetization directions for Hole $982 \mathrm{~B}$, core $6 \mathrm{H}$ vs. meters below sea floor (mb.s.f.), which preserves evidence of the Gauss-Matuyama (G/M) paleomagnetochronozone reversal. Shipboard inclination data are preliminary derived after only AF demagnetization at peak fields of $25 \mathrm{mT}$ (Channell and Lehman, 1999). U-channel (inclination) data are component magnetizations based on regression from alternating field demagnetization at peak fields of 80 and $70 \mathrm{mT}$ and 60 to $20 \mathrm{mT}$ (in $5 \mathrm{mT}$ steps), as described in Channell and Guyodo (2004). Note, u-channel data were only measured on Hole B cores included in the shipboard splice. Based on the preliminary shipboard data, the G/M boundary in Hole B was identified at $52.55 \mathrm{~m}$ b.s.f. (red label and arrow) $(982 \mathrm{~B} 6 \mathrm{H} 7 \mathrm{H}$, $0 \mathrm{~cm}, 58.02 \mathrm{~m}$ composite depth, mcd; Channell and Lehman, 1999). Subsequent post-cruise u-channel analysis has identified the precise depth of the G/M chronozone boundary in Hole B at $51.77 \mathrm{~m}$ b.s.f. (black label and arrow) (982B-6H-6 at $77 \mathrm{~cm}, 57.29 \mathrm{mcd}$; Channell and Guyodo, 2004), which corresponds well to our understanding of the temporal relationships between the G/M chronozone reversal and records of benthic $\delta^{18} \mathrm{O}$ (i.e., peak MIS 103; Ohno et al., 2012).

stratigraphy (Fig. $2 \mathrm{~b}$ and c). In the original assignment of glacial stages to the Site $982 \delta^{18} \mathrm{O}$ stratigraphy, MIS G12 is not well resolved. While MIS G12 is not readily evident in the benthic $\delta^{18} \mathrm{O}$ record in the original age model (Fig. 2a), it is clearly recorded in the alkenone-based SST data set for this site (Fig. 6).

Khelifi et al. (2012) argue that a hiatus proposed by Venz and Hodell (2002) to span MIS 88 to 86 demonstrates that sedimentation at Site 982 was "occasionally discontinuous". They also suggest that Lisiecki and Raymo (2005) generated new benthic $\delta^{18} \mathrm{O}$ data to span this gap before incorporating the benthic $\delta^{18} \mathrm{O}$ stratigraphy of Site 982 into the LR04 (Khelifi et al., 2012). Channell and Guyodo (2004) took the possible existence of this hiatus into consideration when they assigned glacial stage numbers to the Site 982 benthic $\delta^{18} \mathrm{O}$ record (see Channell and Guyodo, 2004; their Fig. 4). Despite the suggestion of Khelifi et al. (2012), no new benthic $\delta^{18} \mathrm{O}$ data were generated by Lisiecki and Raymo (2005) to bridge this gap, and the proposed hiatus is not included in the record during the incorporation of the Site 982 benthic $\delta^{18} \mathrm{O}$ data into the LR04. However, a sharp contact is evident 


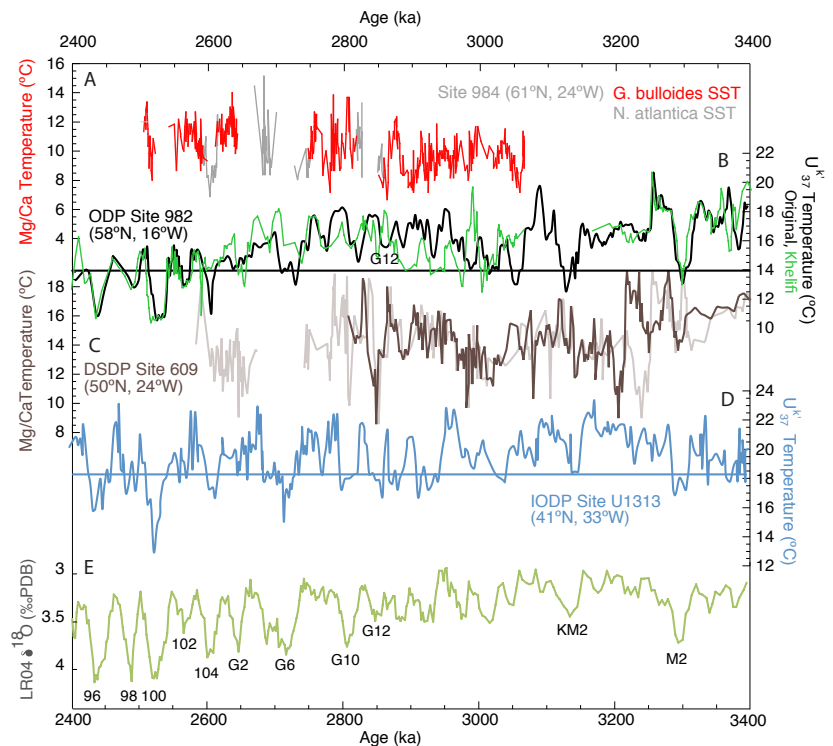

Fig. 6. Pliocene North Atlantic sea surface temperature data: (A) ODP Site $984 \mathrm{Mg} / \mathrm{Ca}$ SST (red=G. bulloides, light gray= $\mathrm{N}$ atlantica) (Bartoli et al., 2005), (B) ODP Site $982 \mathrm{U}_{37}^{K^{\prime}}$ SST (Lawrence et al., 2009) on the original age model (black) (Lisiecki and Raymo, 2005) and the revised age model (green) (Khelifi et al., 2012), (C) DSDP Site $609 \mathrm{Mg} / \mathrm{Ca}$ SST (light brown) (Bartoli et al., 2005) and revised age model (dark brown) (see Supplement), and (D) ODP Site U1313 U $\mathrm{U}_{37}^{K^{\prime}}$ SST (dark blue) (Naafs et al., 2012). (E) LR04 global benthic stack (light green) (Lisiecki and Raymo, 2005) with significant glacial marine isotope stages labeled in black. Horizontal lines in (B) and (D) denote average Holocene SST for Site 982 and Site U1313.

in core photos at approximately the depth of the proposed hiatus (which falls between 49.45 and $49.50 \mathrm{mcd}$, 982C-6H3W, 15-20 cm; Venz and Hodell, 2002). Regardless, no sedimentological evidence exists in core photographs for the proposed hiatus inserted by Khelifi et al. (2012) at 70.19$70.39 \mathrm{mcd}(982 \mathrm{C}-8 \mathrm{H}-3 \mathrm{~W}, 40-60 \mathrm{~cm})$. Moreover, its introduction, which is not justified on the grounds outlined by Khelifi et al. (2012), induces unrealistic spikes in sedimentation rates in the Pliocene portion of the Site 982 record relative to those inferred from the original age model (Fig. $2 b$ and c). In contrast, the original age model shows much smoother variations in sedimentation rates. We acknowledge that while on longer timescales more accurate age models do not tend to be characterized by sharp changes in sedimentation rates, sedimentation rates can be progressively more variable on shorter timescales (Sadler, 1999). An additional way to explore which age model is better is to employ dynamic programming, and indeed, because the Site $982 \delta^{18} \mathrm{O}$ record was one of the records incorporated into the LR04 stack, this approach was already used to optimize the "fit" of the Site 982 original age model to the global variations in benthic $\delta^{18} \mathrm{O}$.

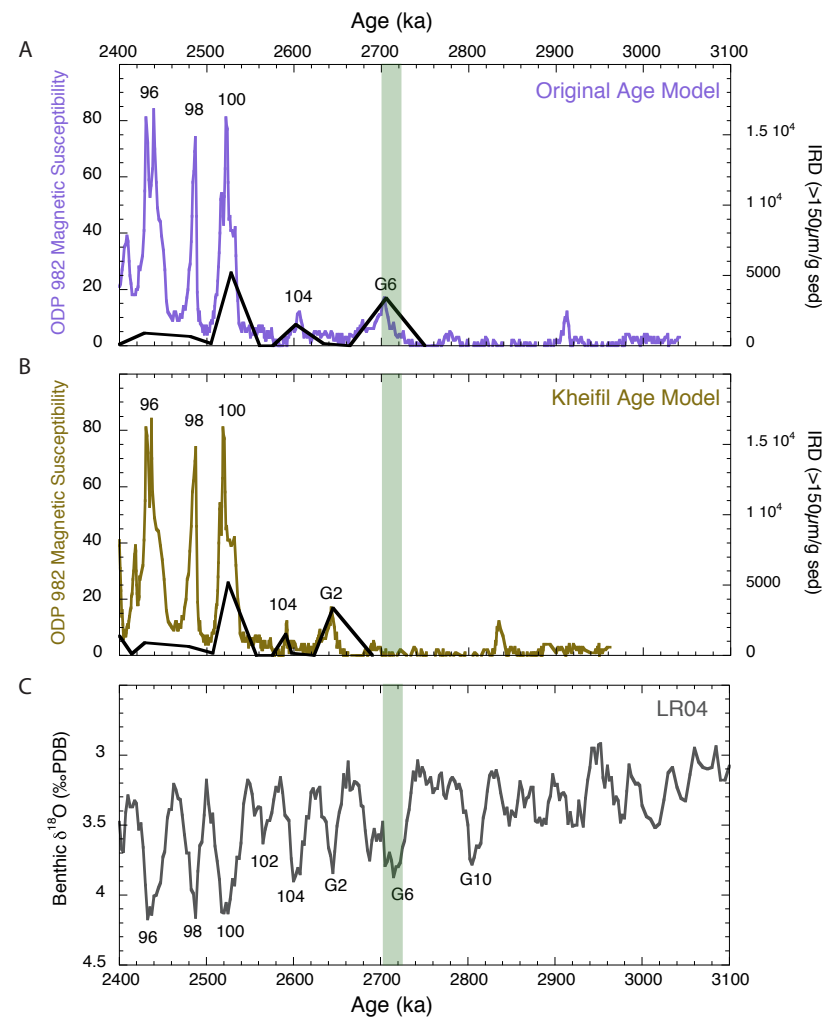

Fig. 7. Site 982 ice-rafted debris (Baumann and Huber, 1999) and magnetic susceptibility data (black) (Shipboard Scientific Party, 1996) plotted on (A) the original age model (purple) (Venz and Hodell, 2002) and (B) the age model proposed by Khelifi et al. (2012) (brown). (C) Benthic oxygen isotope data from the LR04 global benthic stack (Lisiecki and Raymo, 2005) (gray). The vertical green bar highlights the onset of major IRD deposition in the northeast North Atlantic Ocean. Significant glacial marine isotope states are labeled in black.

\section{Regional data comparisons}

One might expect that, in addition to more consistent sedimentation rates, an accurate age model would result in paleoclimate time series from Site 982 that are more consistent with analogous data sets regionally, compared to a less accurate age model. Site 982 SST data using the original Site 982 age model show a fairly strong correlation with SST estimates from other sites in the North Atlantic, in particular Integrated Ocean Drilling Program (IODP) Site U1313 (Fig. 6). In contrast, Site 982 SST data plotted on the Khelifi age model produce a much poorer correlation with other existing North Atlantic SST data (Fig. 6). The superior visual fit of Site 982 SST data on the original age model to other regional SST data sets is also supported by cross-spectral analysis of these data sets. Our analysis indicates that Site U1313 SSTs and Site 982 SSTs plotted on the original age model are highly coherent at the $100 \mathrm{kyr}(0.98)$ and $41 \mathrm{kyr}(0.96)$ orbital frequencies, with significance at the $95 \%$ confidence level. In contrast, when the Khelifi age model is employed 
for the Site 982 SST data set, these two time series are coherent only in the $41 \mathrm{kyr}$ band (0.89) and only at the $80 \%$ confidence level.

IRD deposition has been shown to increase significantly during MIS G6 at 2.72 Ma in the Northeast Atlantic Ocean at ODP Site 984 (Bartoli et al., 2005), DSDP Sites 610 (Kleiven et al., 2002) and 611 (Bailey et al., 2013), and IODP Site U1314 (Hayashi et al., 2010). In concert with other nearby records, the original age model for Site 982 indicates that IRD inputs to this region increase dramatically during MIS G6 (Baumann and Huber, 1999; Shipboard Scientific Party, 1996) (Fig. 7). In contrast, the age model proposed by Khelifi et al. (2012) for Site 982 indicates that the onset of abundant IRD deposition at this site occurred from MIS G2 (2.64 Ma or 80 kyr later) (Fig. 7).

\section{Conclusions}

Recently, Khelifi et al. (2012) proposed a revision to both the composite splice (55-72 mcd, Shipboard Scientific Party, 1996) and the widely accepted age model (Lisiecki and Raymo, 2005) for the Pliocene stratigraphy of ODP Site 982. Here, we demonstrate that neither of the main justifications put forward by Khelifi et al. (2012) for these changes - that shipboard physical property data cannot be used reliably to generate a composite splice below $55 \mathrm{mcd}$ and that shipboard identification of the depth to the Gauss-Matuyama polarity chronozone reversal was in error - is correct. Instead, based on an inspection of the physical property data used to generate the Site 982 splice and the correct application of post-cruise, u-channel-derived inclination and declination data that follow the shipboard splice (following Channell and Guyodo, 2004), we have demonstrated the veracity of the Pliocene portion of the original Site 982 composite splice and age model. We further demonstrate that available Site $982 \mathrm{pa}-$ leoceanographic data are most consistent with other regional data sets when plotted on this age model. We recommend that future use of these data and interpretation of new data sets generated for Site 982 continue to employ both the original shipboard splice (Shipboard Scientific Party, 1996) and age model for the Pliocene portion of this record published by Lisiecki and Raymo (2005).

\section{Supplementary material related to this article is available online at http://www.clim-past.net/9/2391/2013/ cp-9-2391-2013-supplement.pdf.}

Acknowledgements. We are grateful to James Channell for providing relevant information and for productive discussions, and for the data sets plotted in Fig. 5b. We thank Catherine Riihimaki for technical assistance with figures and C. Langereis, L. Lanci and D. Hodell for constructive reviews that helped to improve this manuscript. Support for this work was provided to KTL by
NSF MG\&G grant OCE0623310 and MER by NSF P2C2 grant 1203320.

Edited by: D.-D. Rousseau

\section{References}

Bailey, I., Hole, G. M., Foster, G. L., Wilson, P. A., Storey, C. D., Trueman, C. N., and Raymo, M. E.: An alternative suggestion for the Pliocene onset of major northern hemisphere glaciation based on geochemical provenance of North Atlantic Ocean ice-rafted debris, Quaternary Sci. Rev., 75C, 181-194, doi:10.1016/j.quascirev.2013.06.004, 2013.

Bartoli, G., Sarnthein, M., Weinelt, M., Erlenkeuser, H., GarbeSchonberg, D., and Lea, D.: Final closure of Panama and the onset of northern hemisphere glaciation, Earth Planet. Sc. Lett., 237, 33-44, 2005.

Bartoli, G., Hoenisch, B., and Zeebe, R. E.: Atmospheric $\mathrm{CO}_{2}$ decline during the Pliocene intensification of Northern Hemisphere Glaciation, Paleoceanography, 26, PA4213, doi:10.1029/2010PA002055, 2011.

Baumann, K. H. and Huber, R.: Sea-Surface Gradients Between the North Atlantic and the Norwegian Sea During the Last 3.1 M.Y.: Comparison of Sites 982 and 985, in: Proceedings of the Ocean Drilling Program, Scientific Results, edited by: Raymo, M. E., Jansen, E., Blum, P., and Herbert, T. D., Vol. 162, College Station, Texas, Ocean Drilling Program, 179-190, 1999.

Bolton, C. T., Lawrence, K. T., Gibbs, S. J., Wilson, P. A., and Herbert, T. D.: Biotic and geochemical evidence for a global latitudinal shift in ocean biogeochemistry and export productivity during the late Pliocene, Earth Planet. Sc. Lett., 308, 200-210, 2011.

Channell, J. E. T. and Guyodo, Y.: THe Matuyama Chronozone at ODP 982 (Rockall Bank): Evidence for Decimeter-Scale Magnetization Lock-in Depths, in: Timescales of the Internal Geomagnetic Field, edited by: Channell, J. E. T., Kent, D. V., Lowrie, W., and Meert, J., Vol. 145, AGU Geophysical Monograph, 205-219, 2004.

Channell, J. E. T. and Lehman, B.: Magnetic stratigraphy of North Atlantic Sites 980-984, in: Proceedings of Ocean Drilling Program, Scientific Results, edited by: Raymo, M. E., Jansen, E., Blum, P., and Herbert, T. D., Vol. 162: Colege Station, Texas, Ocean Drilling Program, 113-130, 1999.

Flower, B. P., Oppo, D. W., McManus, J. F., Venz, K. A., Hodell, D. A., and Cullen, J. L.: North Atlantic intermediate to deep water circulation and chemical stratification during the past $1 \mathrm{Myr}$, Paleoceanography, 15, 388-403, 2000.

Hayashi, T., Ohno, M., Acton, G., Guyodo, Y., Evans, H. F., Kanamatsu, T., Komatsu, F., and Murakami, F.: Millennialscale iceberg surges after intensification of Northern Hemisphere Glaciation, Geochem. Geophy. Geosys., Qo9Z20, doi:10.1029/2010GC003132, 2010.

Khélifi, N., Sarnthein, M., and Naafs, B. D. A.: Technical note: Late Pliocene age control and composite depths at ODP Site 982, revisited, Clim. Past, 8, 79-87, doi:10.5194/cp-8-79-2012, 2012.

Kleiven, H. F., Jansen, E., Fronval, T., and Smith, T. M.: Intensification of Northern Hemisphere glaciations in the circum Atlantic region (3.5-2.4 Ma) - ice-rafted detritus evidence, Palaeogeogr. Palaeocl., 184, 213-223, 2002. 
Lawrence, K. T., Herbert, T. D., Brown, C. M., Raymo, M. E., and Haywood, A. M.: High-amplitude variations in North Atlantic sea surface temperature during the early Pliocene warm Period, Paleoceanography, 24, PA2218, doi:10.1029/2008PA001669, 2009.

Lawrence, K. T., Sosdian, S., White, H. E., and Rosenthal, Y.: North Atlantic Climate Evolution Through the Plio-Pleistocene Climate Transitions, Earth Planet. Sc. Lett., 300, 329-342, 2010.

Lisiecki, L. E. and Raymo, M. E.: A Pliocene-Pleistocene stack of 57 globally distributed benthic $\delta^{18} \mathrm{O}$ records, Paleoceanography, 20, PA1003, doi:10.1029/2004PA001071, 2005.

Naafs, D. A., Hefter, J., Acton, G., Haug, G., Martinez-Garcia, A., Pancost, R. D., and Stein, R.: Strengthening of North Atlantic dust sources during the late Pliocene (2.7 Ma), Earth Planet. Sc. Lett., 317, 8-19, 2012.

Ohno, M., Hayashi, T., Komatsu, F., Murakami, F., Zhao, M., Guyodo, Y., Acton, G., Evans, H. F., and Kanamatsu, T.: A detailed paleomagnetic record between 2.1 and $2.75 \mathrm{Ma}$ at IODP Site U1314 in the North Atlantic: Geomagnetic excursions and the Gauss-Matuyama transition, Geochem. Geophy. Geosys., 13, Q12Z39, doi:10.1029/2012GC004080, 2012.

Ortiz, J. D., O'Connell, S., and Mix, A.: Data report: spectral reflectance observations from recovered sediments, in: Proc. ODP, Sci. Results, 162: College Station, TX (Ocean Drilling Program), edited by: Raymo, M. E., Jansen, E., Blum, P., and Herbert, T. D., 259-264, doi:10.2973/odp.proc.sr.162.029.1999, 1999.
Pagani, M., Liu, Z., LaRiviere, J. P., and Ravelo, A. C.: High Earth-system climate sensitivity determined from Pliocene carbon dioxide concentrations, Nat. Geosci., 3, 27-30, 2009.

Sadler, P. M.: On the determination of sediment accumulation rates, in: GeoResearch Forum, v. 5, edited by: Bruns, P. and Hass, H. C., Trans Tech Publications, Zurich, Switzerland, 15-40, 1999.

Shipboard Scientific Party: Site 982, in: Proceedings of the Ocean Drilling Program, Initial Reports, edited by: Jansen, E., Raymo, M. E., Blum, P., Andersen, E. S., Austin, W. E. N., Baumann, K. H., Bout-Roumazeilles, V., Carter, S. J., Channell, J. E. T., Cullen, J. L., Flower, B. P., Higgins, S. M., Hodell, D. A., Hood, J. A., Hyun, S., Ikehara, M., King, T., Larter, R., Lehman, B., Locker, S., McIntyre, K., McManus, J., Meng, L. B., O'Connell, S., Ortiz, J., Rack, F., Solheim, A., and Wei, W., Vol. 162: College Station, Texas, Ocean Drilling Program, 91-138, 1996.

Sosdian, S. and Rosenthal, Y.: Deep-Sea Temperature and Ice Volume Changes Across the Pliocene-Pleistocene Climate Transition, Science, 325, 306-310, 2009.

Venz, K. A. and Hodell, D. A.:, New evidence for changes in PlioPleistocene deep water circulation from Southern Ocean ODP Leg 177 Site 1090, Palaeogeogr. Palaeocl., 182, 197-220, 2002.

Venz, K. A., Hodell, D. A., Stanton, C., and Warnke, D. A.: A 1.0 Myr record of glacial North Atlantic intermediate water variability from ODP site 982 in the northeast Atlantic, Paleoceanography, 14, 42-52, 1999. 